\title{
Penile Cancer pT1 TNM Finding v7
}

National Cancer Institute

\section{Source}

National Cancer Institute. Penile Cancer pT1 TNM Finding v7. NCI Thesaurus. Code C89170.

Penile cancer with tumor invading subepithelial connective tissue without lymph vascular invasion and is not poorly differentiated (i.e., grade 3-4), or tumor invading subepithelial connective tissue with lymph vascular invasion or is poorly differentiated. (from AJCC 7th Ed.) 